ADDITIONAL NOTES ON RECENT OCCURRENCE OF MAMMALS IN THE THELON GAME SANCTUARY, N.W.T.

by Ernie Kuyt, Fort Smith, N.W.T.

MOOSE (Alces alces) - Recently (Blue Jay, 23:134), I summarized evidence found near Lookout Point, indicative of Moose and a few other mammals in the area. During our two and one-half months of field-work this summer (1965) in the Thelon River area, we again failed to see Moose near Lookout Point but on June 18, we found four groups of fresh Moose droppings in almost the same spot (the old Eskimo "logging" site) where this evidence was found in 1963. Finally, on July 3 , while making an aerial reconnaissance in the region of the upper Thelon River, I observed a young bull Moose. The observation was made outside the Thelon Game Sanctuary at about $60^{\circ} 36^{\prime}$ N., $104^{\circ}$ $45^{\prime} \mathrm{W}$. This location is some distance north of the arbitrary tree-line but still about 125 miles southwest of the mouth of the Finnie River, where evidence has shown Moose to be present. BEAVER (Castor canadensis) - Of considerable interest was the sighting on July 31,1965 , of an adult Beaver at approximately $63^{\circ} 59^{\prime} \mathrm{N}$, $103^{\circ} 52^{\prime} \mathrm{W}$. or about four miles upstream of Hornby's Bend on the Thelon River. The animal was first seen on the riverbank, cutting willows (Salix planifolia Pursh), the stems of several of which were floating nearby. Perhaps the animal was in the process of establishing a feed-bed. We watched for some time and the animal, disturbed at our presence, slapped its tail on the water and disappeared. It was observed again on several occasions and remained nearby. The nearest record of Beaver $I$ have been able to find is that of two beaver seen in 1937 on Eileen Lake, on the "treeline" (Clarke, C.H.D. 1940. A Biological investigation of the Thelon Game Sanctuary. Nat. Mus. Canada Bull., $96: 37)$, about 170 miles to the southwest. Barren-ground trappers Gus D'Aoust of Fort Reliance and
Fred Riddle of Stony Rapids, Saskatchewan, who have worked for years in the general area, have not seen signs of Moose or Beaver along the Thelon River. The occurrences of these two species north of their known range, as reported in this note, are undoubtedly recent ones. I would like to express my thanks to Dr. G. W. Argus, Curator of the W. P. Fraser Herbarium, Saskatoon, for making the determination of the willow.

\section{THREE POCKET MOUSE RECORDS}

by Robert W. Nero, Regina

Glen A. Fox reports finding the carcass of an Olive-backed Pocket Mouse (Perognathus fasciatus) and several other rodents in a Swainson's Hawk nest seven miles west of Saskatoon, on July 1, 1965. The nest contained two very young chicks and an unhatched egg (pers. corres., 1965). Recently, Harvey Beck and Robert $R$. Taylor showed me a dead one which they found on a sandy road near White City, 11 miles east of Regina on September 29. On October 2, Hugh Smith and I found a fresh carcass on a trail in a prairie pasture about five and one-half miles west of Craven. These 1965 records are within the known range of the species (see Blue Jay, 16:176-9; 23:36-8), but provide new specific locality records. The White City record is of particular interest for it bridges a gap between records on Cottonwood Creek, about seven and one-half miles west of Regina, and the Strawberry Lakes some 60 miles to the east. During the past several years I have made numerous unsuccessful efforts to find the Pocket Mouse in the sandy plains at White City and Pilot Butte and now its occurrence there has been established simply by picking up a dead one! This points out the difficulty of determining the range of this interesting mammal, which is hard to trap and often apparently of rare occurrence within its known range, and also shows how useful a single specimen may be. 